\title{
Religieuze tolerantie vraagt onderwijs in gastvrijheid
}

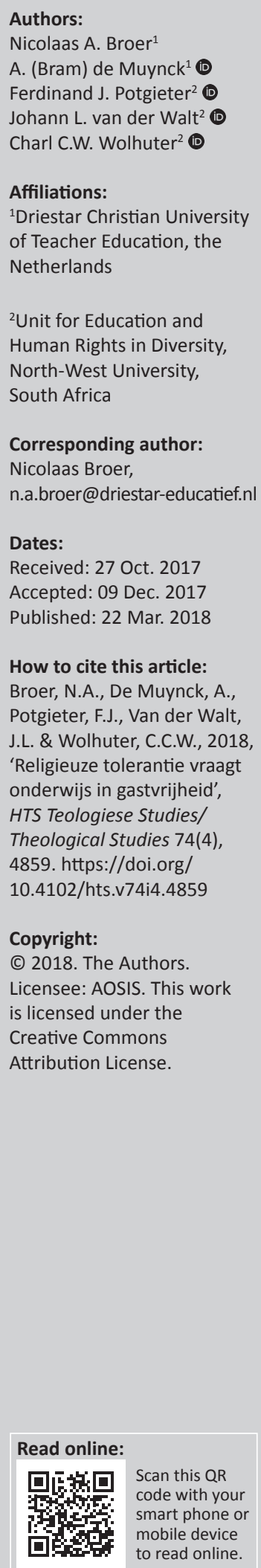

The South African-Dutch research group responsible for this article started its activities in 2012 by looking at religious tolerance (in education) as a means of addressing the tendency for religious intolerance, extremism and fundamentalism. While (teaching in) tolerance seemed to be a promising way to counter religious intolerable behaviour, some shortcomings also became apparent. For example, the concept of tolerance includes an aspect of passivity towards others who adhere to another religion. The concept also does not appear to be able to respond to attitudes and values such as respect, human rights and diversity. Accurate investigation of this problem, both conceptually and empirically, led to the understanding that hospitality is a concept that embodies more active adaptation to those who are different (including religious). Hospitality, therefore, seems to be a more promising concept than tolerance for reducing religious tension between individuals and groups. The inner contradiction discovered by Derrida in the notion of hospitality does not detract from the concept of being defined from a Biblical point of view. Hospitality can also be taught to young people. Although there are no formal provisions for hospitality in the national curricula, an analysis of the Dutch and South African national curricula shows that there is room for hospitality education.

\section{Introductie}

In de geschiedenis van de mensheid doen zich gedurig spanningen, conflicten en geweld voor, zowel tussen individuele personen als tussen samenlevingen en staten (Rodden 2004:335-336). Spanningen tussen mensen die veroorzaakt worden door verschillen in taal, cultuur en religie leiden tot onverdraagzaamheid en meer of minder openlijke agressie. Voorbeelden van spanningsbronnen en de gevolgen daarvan zijn er in Zuid-Afrika, maar ook in Nederland. In Zuid-Afrika worden dagelijks 51 mensen vermoord, terwijl er 150 seksuele en seksueel-verwante misdaden gemeld worden (Engeland 2016). In Nederland doet zich het probleem voor van de stromen vluchtelingen die via andere Europese landen binnenkomen. Tussen 2002 en 2013 was het aantal mensen dat asiel aanvroeg in Nederland stabiel: minder dan 20000 per jaar met een dieptepunt van 9731 in 2007. In 2014 schoot het aantal asielaanvragen echter omhoog naar 29989 en in 2015 naar 58880 (Dijkgraaf 2017:90). De stroom asielzoekers en andere immigranten is een wezenlijk onderdeel van de Nederlandse samenleving geworden. Dat gegeven roept een grote diversiteit aan reacties op die te plaatsen zijn op het continuüm van meer tolerant naar minder tolerant (cf. De Rooy 2014). De Rooy (2014) beschrijft de situatie als volgt:

Was Nederland sinds de jaren zestig een toonbeeld geweest van openheid en tolerantie, sinds de jaren tachtig een voorbeeld van rationeel overleg om problemen op te lossen, nu wezen verschillende ambassadeurs er openlijk op dat 'Nederland een verward en introvert land' was geworden. (p. 270)

Duizenden vluchtelingen stromen dagelijks vanuit het Midden-Oosten over de grenzen van Europa en de leiders van de Europese landen weten daar niet afdoende antwoorden op te vinden (Scholtz 2015:13). Hierdoor ontstaan spanningen tussen individuen en groepen. Het probleem van intolerant gedrag tegenover andere individuen en groepen is een wereldwijd probleem dat in alle gemeenschappen voorkomt (vgl. Anderson 2013; United States Department of State. Bureau of Democracy, Human Rights and Labor 2014).

Om interpersoonlijke conflicten en het geweld waarop zij soms uitlopen het hoofd te bieden, wordt dikwijls een pleidooi gehouden voor tolerantie en onderwijs in tolerantie. Het pleidooi voor onderwijs in tolerantie is onlosmakelijk verbonden met de vraag naar een nadere concretisering van dit begrip.

In het kader van de samenwerking tussen de Noordwes-universiteit (Potchefstroom, Zuid-Afrika) en Driestar (Gouda, Nederland) startte in 2012 een onderzoeksproject met als onderwerp 
'religieuze tolerantie'. Het onderzoek richtte zich op het zichtbaar maken van religieuze tolerantie bij studenten in het laatste jaar van opleiding tot leraar. Deze studenten staan net voor de start van een beroepsloopbaan waarin zij leerlingen moeten vormen tot goede burgers van de samenleving. Daartoe behoort een houding van tolerantie ten opzichte van andersdenkenden. Het is dan van belang om te weten hoe tolerant aankomende leraren zelf zijn. Het onderzoeksproject zou moeten resulteren in een meetinstrument waarmee (religieuze) tolerantie op een efficiënte en betrouwbare manier kan worden gemeten. Dat zou niet alleen in de beide hierboven genoemde landen moeten gebeuren, maar ook daarbuiten.

Als van leraren gevraagd wordt hun leerlingen een tolerante houding bij te brengen, moet duidelijk zijn wat tolerantie is en hoe die in de klas bevorderd kan worden. Het begrip moet zodanig worden geoperationaliseerd dat er concrete handelingssuggesties voor leraren uit kunnen worden afgeleid. De auteurs van dit artikel hebben pogingen ondernomen om het begrip 'tolerantie' zowel te definiëren als te operationaliseren. De definitiekwestie bleek complex te zijn (Potgieter, Van der Walt \& Wolhuter 2014), maar nog meer complex was de operationalisatie (Broer et al. 2016). De vraag dringt zich op of het moeilijk te definiëren en operationaliseren begrip 'tolerantie' zich genoeg leent voor een plaats in het onderwijs. Zonder het begrip 'tolerantie' als achterhaald terzijde te stellen, willen we proberen te bezien, nadat we nader zijn ingegaan op de complexiteit ervan, of het begrip in combinatie met andere begrippen beter bruikbaar lijkt te zijn.

\section{Probleemstelling}

Wij hebben in het genoemde onderzoek met betrekking tot het vraagstuk van (religieuze) tolerantie een aantal dingen ontdekt. Ten eerste ontdekten we dat tolerantie (of verdraagzaamheid) samenhangt met andere houdingen, gezindheden en waarden, zoals: vrijheid, mensenrechten, menswaardigheid en respect (Potgieter et al. 2014; Van der Walt 2014; 2016), alsook met vergevingsgezindheid en gastvrijheid tegenover de vreemde. Tolerantie is slechts één onderdeel van een constellatie van begrippen die verband houden met onze verhouding tot anderen die op een bepaalde manier, vooral religieus, van ons verschillen. Het begrip kan, theoretisch gezien, niet goed als een samenvattend begrip dienen.

Ten tweede bleek ons dat tolerantie op zich niet direct betrekking heeft op gedrag, maar dat het staat voor een houding of gezindheid. Die houding of gezindheid kan onder andere worden gekarakteriseerd als 'passief' en 'asymmetrisch'. Iemand die tolerant is, verdraagt zijn medemens die (religieus) van hem verschilt. Het is niet gemakkelijk om tolerantie zo te definiëren dat het activiteiten ten opzichte van vreemden omvat. Tolerantie heeft ook een aspect van asymmetrie en ongelijkheid in zich. Iemand die tolerant is ten opzichte van een medemens met andere religieuze overtuigingen gaat er, vaak onbewust, vanuit dat zijn eigen opvatting juist is. Vanuit die eigen opvatting verdraagt hij de ander met een zekere passiviteit. Deze karakteristieken van tolerantie bemoeilijken een daadwerkelijk gebruik ervan in het onderwijs.

Nog een derde punt is van belang. Tot nu toe hanteerden we in ons onderzoeksproject het begrip 'religieuze tolerantie'. Het bijvoeglijke naamwoord suggereert een relatie met religie, wereldbeschouwing of levensfilosofie. Die relatie is er wel, maar slechts indirect. Het begrip is niet direct ontleend aan de Bijbel, of aan een ander heilig geschrift. Het gevolg daarvan zou kunnen zijn dat het begrip 'religieuze tolerantie' moeilijk ingang vindt bij scholen en leraren die werken vanuit een bepaalde religieuze of levensbeschouwelijke achtergrond.

Er zijn dus begripstheoretische, methodologische en inhoudelijke bezwaren aan te voeren tegen het gebruik van het begrip '(religieuze) tolerantie'. Echter, als scholen en leraren concrete aanknopingspunten moeten krijgen om (religieuze) intolerantie aan te pakken, is een herbezinning op het tolerantiebegrip in het onderwijs nodig. De vraag is niet in de eerste plaats waardoor het begrip '(religieuze) tolerantie' moet worden vervangen. Verdraagzaamheid als grondhouding blijft van groot belang voor burgerschap. Onze zoektocht betreft een zodanige aanvulling van de aangegeven tekorten dat het burgerschapsonderwijs beter bediend wordt. De vraag die in dit artikel beantwoord wordt, is dan ook:

Hoe kan het begrip '(religieuze) tolerantie' zodanig worden aangevuld dat het goed bruikbaar is in het kader van de pedagogische opdracht van het onderwijs, namelijk het vormen van leerlingen tot burgers die een positieve bijdrage aan de samenleving leveren?

\section{Doel van het artikel}

Het onderwijs op scholen beoogt een pedagogische opdracht uit te voeren. Daartoe behoort dat de leerlingen worden gevormd tot goede burgers. Tot goed burgerschap behoort dat mensen goed met elkaar omgaan. Voor een definitie van 'goed burgerschap' beroepen wij ons op de Bijbel. In de Bijbel worden enkele begrippen gehanteerd die sterk gerelateerd zijn aan het goed omgaan met elkaar, namelijk 'gastvrijheid'. Met de keuze voor deze begrippen volgen we de suggestie van Pohl (1999) die ontdekte dat gastvrijheid te maken heeft met opvattingen over tolerantie, maar er ook in belangrijke mate van verschilt. Haar analyse van de geschiedenis van gastvrijheid heeft een aantal onderzoekers op het spoor gebracht om gastvrijheid ook toe te passen in het onderwijs (o.a. Anderson 2011; Burwell \& Huyser 2013; Call 2011). Om die reden wordt dit begrip theoretisch verkend om daarmee vast te stellen of 'gastvrijheid' inderdaad Bijbels te funderen is en tevens goed te gebruiken is in het kader van de pedagogische opdracht van het onderwijs. Een belangrijk uitgangspunt hierbij is dat een theoretisch houvast nodig is om in de onderwijspraktijk de goede dingen te kunnen doen. Het doel van dit artikel is dus om een theoretische basis te leggen op grond waarvan aan scholen en leraren concrete 
handreikingen kunnen worden gegeven om de pedagogische opdracht beter vorm te kunnen geven. Uiteindelijk moet dit artikel dus dienstbaar zijn aan de vorming van leerlingen tot goede burgers.

Om de probleemstelling te kunnen beantwoorden en een eerste stap te zetten in de richting van het doel is het artikel als volgt gestructureerd. De volgende twee paragrafen bevatten een uiteenzetting van het proces dat leidde tot de conclusie dat het begrip 'tolerantie' bij nader inzien niet goed genoeg bruikbaar is in het onderwijs. Eerst wordt een theoretische invalshoek gekozen en daarna wordt gerefereerd aan empirisch onderzoek dat in de periode 2014 tot 2017 is uitgevoerd. Vervolgens wordt het begrip 'gastvrijheid' ontleed om vast te kunnen stellen of dit begrip, mogelijk als completering van 'tolerantie', goede aanknopingspunten biedt voor implementatie in het onderwijs. Nadat hieruit de nodige conclusies zijn getrokken, wordt 'gastvrijheid' nader onderzocht vanuit een Bijbels perspectief. Ten slotte wordt aandacht besteed aan de betekenis van dit alles voor gastvrijheidsonderwijs in het kader van het onderwijs en de lerarenopleiding.

\section{Theoretisch raamwerk Het begrip 'godsdienstige tolerantie'}

Met behulp van literatuurstudie is in de eerste fase van het onderzoek gepoogd een schets te geven van het concept 'religieuze tolerantie' (Potgieter et al. 2014; Van der Walt 2014). Aan dat concept wordt een verscheidenheid van betekenissen gehecht. Potgieter et al. (2014) proberen om op grond van een semantische analyse de essenties van het concept te expliciteren. Volgens deze onderzoekers duidt tolerantie (of: verdraagzaamheid) op een staat, een toestand of een geneigdheid van een persoon ten opzichte van een andere persoon of groep die als ongewenst wordt ervaren. Hiermee wordt duidelijk gemaakt dat tolerantie een houding (attitude) of gezindheid van een persoon is. Dat wordt ook duidelijk uit het gegeven dat tolerantie te maken heeft met de afwijking van een gegeven standaard, norm, beginsel of waarde die een persoon bereid is toe te laten (Potgieter et al. 2014). Iemand laat een afwijking toe na een beslissing die hij neemt met verwijzing naar een in de gemeenschap aanvaarde waardenhiërarchie (ibid.). Tolerantie heeft de connotaties van geduld en beleefdheid en betekent dat iemand zich bewust is van zichzelf in verhouding tot de ander en het gedrag van die ander aanvaardt alsof het zijn eigen gedrag is (Zakin 2012). Een verdraagzame persoon huldigt de overtuiging dat de mensheid verrijkt wordt door het toelaten van verscheidenheid aan manieren van leven, omdat daardoor al experimenterend van elkaar geleerd kan worden (Potgieter et al. 2014).

Onlangs gepubliceerd empirisch onderzoek in Duitsland en Nederland toont aan dat de opvattingen over religie onder de inwoners van die landen heel bepalend is voor de al dan niet tolerante houding ten opzichte van medemensen. Wat iemand waarneemt en aanneemt als de religieuze overtuiging van de andere persoon blijkt zijn hele houding of gezindheid tegenover die andere persoon te bepalen (Erisen \& KenmenCin 2017). Zeker als (een houding van) intolerantie leidt tot religieus extremisme is het voor een samenleving van belang daar een antwoord op te geven. Religieuze tolerantie wordt dan als een eerste stap gezien op weg naar het scheppen van een samenleving waarin iedereen loyaal is (Naumenko \& Naumenko 2016:335). Tolerantie is een noodzakelijk element van interculturele communicatie. Dat is het vermogen om belangrijke zaken niet op zichzelf te begrijpen, maar de waarde daarvan te peilen in het kader van een andere cultuur (Aubakirova et al. 2016:5034).

Naast de opvatting dat het belangrijk is om na te denken over religieuze tolerantie als antwoord op religieus extremisme zijn er ook kanttekeningen te plaatsen bij het tolerantie-idee. In de laatste jaren is er, als onderdeel van een grotere discussie, kritiek geuit tegen het idee van tolerantie, ook specifiek tegen religieuze tolerantie. Enerzijds is er het bezwaar dat Carson (2012) in zijn boek The Intolerance of Tolerance uiteenzet. Dat komt erop neer dat tolerantie vaak (vooral in de Westerse samenlevingen) zover doorgevoerd wordt dat een persoon eigenlijk geen mening mag ventileren die verschilt van de mening van een ander. In die zin is tolerantie geworden tot een contradictio in terminus, omdat het beginsel van de vrijheid van meningsuiting ermee ontkend wordt (vgl. Carson 2012). Anderzijds bestaat onder progressief ingestelde opiniemakers en onderzoekers de mening dat tolerantie een bevoorrechte positie schept ('wij' tegenover 'de anderen'), waardoor asymmetrische machtsverhoudingen en ongelijkheid worden versterkt (Beaman 2011). Het laatste gevaar is vooral aanwezig in situaties van interraciaal contact en in situaties waarin de gevolgen van een koloniale geschiedenis manifest zijn (ibid.). In hoeverre en op welke gebieden tolerantie gevraagd wordt, is dus altijd afhankelijk van machtsaspecten. De groep die dominant is, bepaalt de grenzen van wat getolereerd moet worden. In Nederland wordt er bijvoorbeeld vanuit gegaan dat moslims zich conformeren aan de Westerse moraal. Dit wordt door de moslimgemeenschap als zeer intolerant ervaren (De Rooy 2014; Visser-Vogel 2015:116-118).

\section{Tolerantie bezien vanuit empirisch onderzoek}

Nadat het tolerantiebegrip theoretisch was onderbouwd (Potgieter et al. 2014) volgde er een proces waarin getracht werd een efficiënt, valide en betrouwbaar meetinstrument te construeren, rekening houdend metbepaalde methodologische vooronderstellingen (Van der Walt \& Potgieter 2012). Op grond van deze theoretische overwegingen werd een vragenlijst samengesteld. Deze werd in diverse talen vertaald en afgenomen bij studenten in lerarenopleidingen. Op de gegevens die de afnames opleverden, werden de nodige statistische analyses uitgevoerd om de structuur en de betrouwbaarheid van de vragenlijst vast te stellen. Dat leidde tot bijstelling van de vragenlijst. De volgende versie werd online afgenomen bij grotere groepen studenten en in meer landen dan in de eerste ronde. Ook na deze afname werden 
door statistisch onderzoek de validiteit en de betrouwbaarheid van de vragenlijst nagegaan. Dit empirische onderzoek leverde een bepaald beeld op van (religieuze) tolerantie bij laatstejaars studenten in de lerarenopleiding. Het onderzoek stelde ons ook voor nieuwe vragen.

Ten eerste bleek het heel lastig te zijn om met éénzelfde vragenlijst de mate van tolerantie te meten bij studenten in diverse delen van de wereld. De hoeveelheid verklaarde variantie bleek steeds in de totale dataset (groepen studenten uit verschillende landen samengevoegd) duidelijk kleiner te zijn dan in de afzonderlijke datasets (groepen studenten in één bepaald land). De homogeniteit binnen de afzonderlijke groepen studenten was groter dan die van de totale groep die aan het onderzoek deelnam. Daaruit kan worden geconcludeerd dat nationale, culturele, politieke, religieuze en andere factoren die met de context te maken hebben van belang zijn (Broer et al. 2016).

Ten tweede bleek het complex te zijn om de theoretische overwegingen ten aanzien van (religieuze) tolerantie te operationaliseren in een valide vragenlijst. Factoranalyses brachten de constituerende elementen van de vragenlijst aan het licht (in de vorm van subschalen), maar die kwamen slechts ten dele overeen met het beeld dat voortkwam uit het theoretische onderzoek (Broer et al. 2016). Bovendien bleken de subschalen sterk te verschillen wat de betrouwbaarheid betreft.

Ten derde, in alle analyses kwamen in ieder geval twee factoren duidelijk aan het licht: 'respect' en 'waarde die men hecht aan de eigen religie'. Bij 'respect' valt te denken aan de positieve waardering die iemand heeft voor de verschillen die er in de samenleving zijn en de bijdrage die hij/zij kan leveren om die verschillen te overbruggen. Bij 'de waarde die men hecht aan de eigen religie' gaat het erom dat de persoon zich bewust is van de plaats die de eigen religie in zijn/haar leven heeft en de overtuiging van de juistheid van die religie. De schalen waarmee deze factoren gemeten werden, waren behoorlijk betrouwbaar. Andere elementen uit de theorie over tolerantie kwamen minder consistent tot uiting in de analyses. Te denken valt hierbij aan factoren als: inclusiviteit, exclusiviteit, onverschilligheid, herkomst van de eigen waarden en normen, veranderbaarheid van de eigen waarden en normen, omgang met anderen. Deze factoren waren soms herkenbaar in de analyses, maar andere keren ook niet (Broer et al. 2014). Een oorzaak daarvan zal gelegen zijn in het feit dat het grote verschil in contexten waar de dataverzameling plaatsvond een valide meting in de weg stond. Het is niet geheel duidelijk waar dit toe zou moeten leiden: óf de theoretische overwegingen moeten worden aangepast, óf de operationalisering van de theorie in de vragenlijst moet worden veranderd. Een derde optie zou zijn om de dataverzameling niet te laten verlopen via een vragenlijst, maar via interviews, of observaties.

\section{Noodzakelijke uitbreiding}

In de voorafgaande paragrafen stond zowel vanuit theoretisch als empirisch onderzoek het begrip 'religieuze tolerantie' centraal. Terugkoppeling van de bevindingen uit het empirische onderzoek naar de theorie leidt tot de conclusie dat het begrip 'religieuze tolerantie' zoals dat in ons theoretisch raamwerk werd gedefinieerd en in het empirisch onderzoek werd geoperationaliseerd aan herziening toe is, in die zin dat het minstens aangevuld zou moeten worden. Dat is ook de conclusie van Potgieter (2016:34-35) nadat hij een literatuursearch heeft gedaan. Het begrip tolerantie moet gebruikt blijven worden omdat de houding van verdraagzaamheid belangrijk blijft; echter, zoals we zagen, drukt zij een te grote passiviteit uit. Om het begrip 'religieuze tolerantie' beter bruikbaar te maken, moet het worden uitgebreid.

Tolerantie ten opzichte van anderen en hun religies en culturen kan opgevat worden als afstand houden tot de ander en louter accepteren dat de ander in enig opzicht verschilt van ons. Daartegenover zijn begrippen als 'gastvrijheid' en 'gastvrijheidsonderwijs' actiever van inhoud en zijn ze verbonden met ideeën als openheid, verwelkoming en verbinding. Anderson (2011:14) gebruikt in verband met inclusief onderwijs een overvloed aan woorden en uitdrukkingen die dergelijke ideeën van openheid, verwelkoming en toebehoren omvatten. Hij zegt bijvoorbeeld dat een gastvrije persoon iemand is die anderen tegemoet komt door aan hun persoonlijke behoeften en verwachtingen te voldoen, die hen een thuis biedt in zijn gemeenschap, die hen als een gelijke van de gemeenschap verwelkomt, die zich richt op hun speciale sterktes, noden en behoeften, die hun verbondenheid bevordert in de gemeenschap en die zich inspant om de anderen effectief op te nemen in zijn gemeenschap (Anderson 2011:14). Gastvrijheid verwijst naar menselijke verbondenheid en verworteling in een veilige, betekenisvolle plaats in de wereld, waardoor de gemarginaliseerde, de onaanzienlijke en de buitenstaander tot deel van de gemeenschap worden gemaakt. Gastvrijheid komt overeen met de effectieve incorporatie van de ander die op een of andere manier van onze eigen gemeenschap (bijvoorbeeld een klaslokaal vol studenten) verschilt (Anderson 2011:15).

Anderson (2011:15) waarschuwt ervoor om gastvrijheid te verwarren met toegankelijkheid. Toegankelijkheid betekent slechts dat de deuren voor de ander worden geopend. Gastvrij is het om de ander uit te nodigen en hem of haar welkom te heten en deel van de gemeenschap te maken. In die zin gaat de gastvrijheid veel verder dan alleen het tolereren van de ander die 'buiten' mag worden gelaten, alhoewel de 'deur in beginsel open is' voor hem of haar. Anders gezegd, gastvrijheid bewerkstelligt gemeenschap (Francis 2012:48). Bij het aanbieden van gastvrijheid bevindt de gastheer zich op het snijvlak van de visie van enerzijds Gods koninkrijk waar overvloed is, en anderzijds de harde realiteit van het menselijk bestaan waar de deuren gesloten en vergrendeld zijn, waar behoeftige mensen worden weggedaan of buiten gesloten (Francis 2012:56). Gastvrijheid versterkt relaties, bouwt vriendschappen en draagt bij aan christelijk discipelschap. Daarbij komt, zoals Francis 
(2012:132) aangeeft, dat gastvrijheid niet cultureel gebonden is en gemakkelijk kan worden vormgegeven in een bepaalde situatie. Het is een dagelijkse praktijk die aan vriend en vreemdeling kan worden aangeboden, en het brengt voordeel en zegen voor zowel de gever als de ontvanger van gastvrijheid.

Uit het bovenstaande blijkt dat gastvrijheid positiever en actiever wordt beschreven dan tolerantie. Waar tolerantie neerkomt op oppervlakkige en afstandelijke omgang met de ander, wordt gastvrijheid gekenmerkt door positieve bevestiging van de ander in de vorm van het daadwerkelijk wegnemen van barrières en het bouwen van bruggen tussen mensen die in religieus en cultureel opzicht van elkaar verschillen. Gastvrijheid is bedoeld om de angst en onwetendheid van de ander te verdrijven; het ademt een sfeer van verwelkoming en van de bevestiging van de waardigheid van de ander, de erkenning van onderlinge afhankelijkheid, ongeacht de omvang van de verschillen tussen mensen, en het bevorderen van het gevoel thuis te zijn (bijvoorbeeld in een klaslokaal waar studenten religieuze of culturele verschillen vertonen). Gastvrijheid is ook positief omdat het wordt gekenmerkt door vriendelijkheid, emotionele ondersteuning, zeggenschap en persoonlijke betrokkenheid (Anderson 2011:20-23). In die geest wordt ook in de Bijbel over dit begrip gesproken.

\section{Gastvrijheid als een Bijbels begrip}

In het Oude Testament komt het woord 'gastvrijheid' niet voor. Wel wordt op verschillende plaatsen het zelfstandig naamwoord 'herberg' (Hebr. malon en melunah) gebruikt. Deze Hebreeuwse woorden duiden op een plaats waar iemand overnacht, een nachtkwartier in het leger of de nachthut van een wachter in een wijngaard. Op enkele plaatsen in het Oude Testament wordt het werkwoord 'herbergen' (Hebr. haali'n) gebruikt, namelijk in 1 Koningen 17:20, Job 41:13 en Jesaja 1:21. Vooral de eerste tekst heeft betrekking op een Oudtestamentisch verhaal. Anderson (2011:15) verwijst naar Oudtestamentische verhalen om de praktijk van gastvrijheid te verduidelijken, waaronder Genesis 18 en 19 waar vreemdelingen door respectievelijk Abraham en Lot verzorgd worden; 1 Koningen 17 waar de weduwe van Zarfath Elia onderdak biedt en 2 Koningen 4, het verhaal van Elisa en de Sunamitische vrouw.

Het woord 'gastvrijheid' houdt verband met een Grieks woord wat in het Nieuwe Testament gebruikt wordt, namelijk zenizein wat verwijst naar de ontvangst van een gast (vgl. Hand 10:23 en 28:7). Het zelfstandig naamwoord philoxenia komt in het Nieuwe Testament voor in Hebreeën 13:2 en Romeinen 12:13 (Kruger 2017:8). Dit is de stam van de Griekse grondwoorden die in het Nieuwe Testament met 'gastvrijheid' en 'gastvrij' worden vertaald. Letterlijk betekent dat: het liefhebben van vreemdelingen of gasten (Rom. 12:13; 1 Tim 3:2, 5:10; Tit 1:8). Deze stam komt ook voor in philoxein, waar het verwijst naar het betonen van gastvrijheid aan vreemdelingen (Heb 13:2; 1 Pet 4:8-11; Anderson 2011:16). Dit woord verwijst niet letterlijk naar liefde voor vreemdelingen als zodanig, maar naar een genoegen in de gehele gastheer-gastrelatie, in de mysterieuze resultaten en wendingen die zich kunnen voordoen. De logische uitbreiding van philoxë̈ne ten opzichte van xenizein (Gr. om een gast te ontvangen) is dat er in het verlenen en ontvangen van gastvrijheid een intrinsieke uitwisseling van genade is (Francis 2012:14). Het is belangrijk om erop te letten dat gastvrijheid niet in de eerste plaats te maken heeft met gezellig verkeer tussen vrienden of familieleden, maar dat het gaat om de ontvangst van vreemdelingen. Volgens Anderson (2011:16-17) is de verzoening van Christus aan het kruis, waardoor onze vervreemding van God weggenomen wordt, het ultieme voorbeeld van Gods gave aan alle mensen. Gastvrijheid, beweert hij, betekent ruimte maken voor anderen, zoals God aan het kruis in Zichzelf ruimte maakte voor anderen en Zijn armen uitbreidde om hen te verwelkomen.

In Mattheüs 25:31-46, de gelijkenis van de schapen en de bokken, legt Jezus uit wat het betekent om te dienen in Gods koninkrijk: zonder aanzien des persoons voorzien in menselijke behoeften, het tonen van genade aan vreemdelingen, aan mensen die hongerig, gevangen, arm, ziek of gehandicapt zijn. Aan hen moet gastvrijheid worden getoond, alsof het Jezus zelf betreft. In Lukas 14:16-23, de gelijkenis van het grote feestmaal waar de gemarginaliseerden worden verwelkomd, demonstreert Jezus de onderscheiden kenmerken van christelijke gastvrijheid: de mogelijkheid dat we, door het verwelkomen van de minste broeder of zuster en een gerichtheid op degenen die weinig weder te vergelden hebben, Jezus zelf verwelkomen. De gelijkenis van de barmhartige Samaritaan helpt ons op zijn beurt te begrijpen dat wanneer we iemand in nood zien, die persoon niet moet worden gemeden. We moeten onszelf liever beschouwen als de naaste van die persoon (Anderson 2011:15-16). Gastvrijheid vormt het hart van Jezus' bediening, of het nu het verwelkomen van verworpenen of het eten met tollenaars en zondaren betreft. Nieuwtestamentische christenen volgden Jezus' voorbeeld na door gastvrijheid te beoefenen in de gestalte van de vroege kerk die alles met elkaar deelde (Hand 2:42-47; Francis 2012:132). In Hebreeën 13:1-5 wordt de liefde van gelovigen voor mensen in de samenleving beschreven, namelijk liefde voor broeders en zusters, liefde voor vreemdelingen en liefde voor gevangenen. Dit wordt ondersteund door het motief van gelovigen als een trekkend volk (mensen die onderweg zijn door deze wereld). Hebreeën 13:14 noemt verder dat gelovigen vreemdelingen in de wereld zijn die op zoek zijn naar de toekomende wereld. Daarom stelt de Hebreeënschrijver dat gelovigen krachtens hun aard zelf vreemdelingen zijn en daarom als vreemdelingen aan andere vreemdelingen gastvrijheid moeten bewijzen (Kruger 2017:9).

De Bijbel ziet een verband tussen gastvrijheid en gemeenschap. Om deze reden spelen maaltijden zo'n belangrijke rol in de Bijbel. In het Nieuwe Testament worden minstens zeventien maaltijden genoemd. Maaltijden zijn een belichaming van Jezus' aanvaarding van uitgestotenen en 
een demonstratie van de genade en de aanwezigheid van Gods koninkrijk (Heb 13:2; Openb 3:20; Francis 2012:9, 12). Francis (2012:132) concludeert dat voor Christenen die de zegeningen van de tafel des Heeren kennen, van Psalm 23 tot Jezus' woorden 'doe dat tot Mij gedachtenis' in het laatste Avondmaal, gastvrijheid een profetische activiteit is, omdat het een proclamatie is van Gods Koninkrijk waar iedereen welkom is en er voor iedereen brood zal zijn. Wright (1996:45-48) verbindt aan de vierde bede uit het Onze Vader ('Geef ons heden ons dagelijks brood') de oproep om niet alleen vóór hongerige mensen te bidden, maar ook mét hen en dat vooral te doen tijdens de viering van het Heilig Avondmaal. Zo kan een Christen die aan de tafel ontvangen is door de Grote Gastheer zelf een gastheer zijn of worden voor anderen die honger hebben - zowel lichamelijke als geestelijke honger.

Naar onze mening moeten de bovenstaande Bijbelse gegevens die betrekking hebben op gastvrijheid als maatgevend worden beschouwd en dus als normatief voor gastvrijheid, zelfs in de 21e eeuw, in scholen en klaslokalen die bevolkt worden door studenten die een breed scala aan religieuze en andere verschillen vertonen.

\section{Kanttekeningen bij het gastvrijheidsbegrip}

Zoals Anderson (2011:15) opmerkt, wordt de term gastorijheid tegenwoordig zelden gebruikt buiten het gastvrijheidsbedrijf waar service tegen betaling wordt verleend. Het beeld dat wij schetsen van gastvrijheid heeft echter betrekking op het gedrag jegens de ander, in die zin dat de belangen van de ander zodanig wordt opgevat alsof het de eigen belangen zijn. Dit is ook van belang voor de pedagogische ruimte in het klaslokaal.

Derrida (2001:3-26), die studie heeft gemaakt van gastvrijheid, benadrukt dat we eerst de begrippen 'vreemdheid' en 'ongewoonheid' moeten begrijpen, alvorens we kunnen nadenken over gastvrijheid. Gastvrijheid wordt dan het verwelkomen 'in ons huis' van de ander die niet onze taal spreekt of niet onze waarden deelt. Een eerste stap in het verwelkomen, het gastvrij-zijn, is de erkenning van de ander als 'de ander', de vreemdeling, iemand die anders is. Gastvrijheid, in de opvatting van Derrida, is het tegenovergestelde van vijandigheid. Het is namelijk het maken van de vijand tot vriend (Hemmington \& Gibbons 2017:118-119).

Een ander punt dat Derrida (2000:14) maakt, is dat gastvrijheid een aporetisch karakter heeft in die zin dat het in zichzelf een contradictie herbergt, namelijk dat gastvrijheid ondenkbaar en niet te begrijpen is in een onvoorwaardelijke of absolute zin (vgl. ook Derrida 2002:362; aporia: een onoplosbare interne tegenstelling of logische disjunctie in de notie van gastvrijheid). In het geval van absolute gastvrijheid geeft iemand alles wat hij heeft aan een ander, zonder enige vergoeding of wederkerigheid (Derrida 1999:83), zonder voorwaarden (Derrida 2001:59). Als iemand weigert zo'n gastvrijheid ten toon te spreiden, kan daar een wederzijdse uitwisseling van gewelddadigheid uit voortvloeien (Derrida 2002:398). Door de ander uit te nodigen brengt de gastheer zijn eigen veiligheid en onafhankelijkheid in gevaar (Derrida 1999:94). De gastheer loopt dan het gevaar om de gijzelaar van de gast te worden en de gast wordt de meester. Derrida (2002:41) concludeert dat er op basis van deze visie op gastvrijheid, die een innerlijke tegenstrijdigheid bevat, geen vaste toestand van gastvrijheid is, omdat openheid voor het appèl van de ander neerkomt op openheid voor het anders-zijn.

De innerlijke tegenstrijdigheid die volgens Derrida in gastvrijheid aanwezig is, kan worden opgelost door aandacht te hebben voor beide kanten van gastvrijheid, namelijk enerzijds de autoriteit van de gastheer en anderzijds grenzen die vreemdelingen mogen overschrijden om welkom te geraken in de gemeenschap (thuis) van de gastheer. Volgens Derrida wordt een vreemde van binnenuit (door de gastheer) welkom geheten, onder de voorwaarde dat de verwelkoming de soevereiniteit van de gastheer niet aantast (Hemmington \& Gibbons 2017:121). Op grond van deze visie op gastvrijheid concluderen Hemmington en Gibbons (2017:122) dat de wet van de gastvrijheid van dien aard is dat de gastheer gebonden is aan de gast. Om de mogelijkheid te hebben om zijn gastheerschap te tonen en zijn soevereiniteit te handhaven is hij afhankelijk van zijn gast. Als de gastheer 'ja' zegt tegen de ander is dat een gebaar waaraan de ander kan zien dat de gastheer hem of haar graag wil verwelkomen. Dit vraagt van de gastheer dat hij mogelijkheden biedt die verder gaan dan de door elke religie of cultuur gedefinieerde ruimte (Hemmington \& Gibbons 2017:124).

Verder concluderen Hemmington en Gibbons (2017:127) dat, hoewel Derrida suggereert dat ware gastvrijheid onvoorwaardelijk moet zijn, hij door het begrip aporia duidelijk maakt dat onvoorwaardelijkheid eigenlijk niet mogelijk is. Allegastvrijheid is begrensd door voorwaardelijke transacties. Vraagstukken rond die transacties zijn onder meer de gastheer-gast relaties (bijvoorbeeld het vragen van de naam van de potentiële gast en het reageren daarop door de gast), ideeën van vrijgevigheid en wederkerigheid (geven en nemen) en uitdagingen in verband met feedback.

De aporia-kijk op gastvrijheid geeft een probleem om in Bijbelse zin van ware gastvrijheid te spreken. In de Bijbel is namelijk in verband met ware gastvrijheid sprake van onvoorwaardelijkheid, openheid en genade. Het is waar, zoals Francis (2012:48) betoogt, dat gastvrijheid de levens vormt van zowel de gastheer als de gast. De aard van de gedeelde gastvrijheid geeft vorm aan de manier waarop ze een relatie aangaan en een (nieuwe) gemeenschap vormen. Daarom stelt Kruger (2017:8) dat de gedachte van openheid voor vreemdelingen besloten is in de kern van gastvrijheid. Als we de aporia-gedachte serieus nemen betekent gastvrijheid dus een waagstuk. De omkering van gast en gastheer blijkt risico's met zich mee te brengen en daarom is gastvrijheid in Bijbelse zin bepaald niet goedkoop. 


\section{Gastvrijheidsonderwijs}

$\mathrm{Na}$ het voorgaande pleidooi om het tolerantiebegrip uit te breiden met 'gastvrijheid' en de Bijbelse fundering van het gastvrijheidsbegrip, is de vraag welke betekenis dit heeft voor het onderwijs. Daarbij moet worden bedacht wat de taak en opdracht van het onderwijs is.

Zowel in Zuid-Afrika als in Nederland zijn er officiële overheidsdocumenten waarin geschreven wordt over de inhoud van het onderwijs. Daarin wordt niet specifiek gerefereerd aan gastvrijheid of gastvrijheidsonderwijs, maar wel aan noties die daaraan gerelateerd zijn. Volgens het Curriculum and Assessment Policy Statement (CAPS)/National Curriculum Statement Grades R-12 (DBE 2011) is het algemene doel van het Zuid-Afrikaanse onderwijs:

to ensure that the educational imbalances of the past are redressed, and that equal educational opportunities are provided to all sections of the population. In the process, attention will be given to human rights, inclusivity, environmental and social justice. (pp. 4-5)

De drie termen die hier genoemd worden (mensenrechten, inclusiviteit en sociale gerechtigheid) zijn sterk gerelateerd aan het begrip 'gastvrijheid', zoals dat hierboven aan de orde is gesteld. Dat geldt ook voor de stelling dat inclusiviteit het centrale onderdeel moet worden van de organisatie, de planning en het onderwijs in iedere school.

Ook in Nederlandse officiële documenten komen elementen voor die gerelateerd zijn aan gastvrijheid(sonderwijs). Zo zijn er voor het Nederlandse basisonderwijs kerndoelen geformuleerd waarin het volgende te lezen staat (Greven \& Letschert 2006:51): de leerlingen leren zorg te dragen voor de lichamelijke en psychische gezondheid van henzelf en anderen (kerndoel 34) en: de leerlingen leren zich te gedragen vanuit respect voor algemeen aanvaarde waarden en normen (kerndoel 37). Evenmin als in de Zuid-Afrikaanse documenten wordt in de Nederlandse direct gerefereerd aan de begrippen 'gastvrijheid' of 'gastvrijheidsonderwijs'. 'Zorg dragen' heeft geen wederzijdsheid in zich, laat staan dat er een risico mee genomen wordt. Maar er zijn wel noties terug te vinden die gerelateerd zijn aan gastvrijheid als waarde die van belang is in het onderwijs.

Uit de officiële beleidsdocumenten valt niet op te maken hoe waarden in het onderwijs gestalte kunnen of moeten krijgen. Dat geldt ook voor 'gastvrijheid'. Er zijn echter diverse conceptuele en praktische uitwerkingen waarin gastvrijheid expliciet een rol speelt.

Anderson (2011:14, 15) ziet gastvrijheid als een Bijbels concept én als een eigenschap van schoolklassen die werkelijk inclusief zijn. In gastvrije schoolklassen wordt diversiteit niet gezien als een bedreiging, maar het wordt verwelkomd. Het vraagt wat van de leraar om dit te bereiken, vooral als het leerlingen betreft met een beperking. Zij moeten door de leraar met bewust gekozen woorden en daden welkom worden geheten (Anderson 2011:17). Niet de beperking maar de leerling zelf moet op de voorgrond staan. In een gastvrije schoolklas is de leraar toonbeeld van heling en verzoening. Hij zal serieuze pogingen doen om onwetendheid over beperkingen in het algemeen en de beperking van een medeleerling in het bijzonder te bestrijden. Hij tolereert geen onvriendelijke taal die anderen buitenspel zet of blokkades opwerpt tussen leerlingen. De gastvrije leraar is gericht op gedifferentieerde leerstrategieën en meervoudige intelligentie. Hij bevordert wederkerigheid in de relaties die zijn leerlingen met elkaar hebben. Het klimaat in een gastvrije schoolklas kan worden samengevat met vier begrippen: bescherming, emotionele ondersteuning, empowerment (emancipatie), en persoonlijke betrokkenheid.

Samen met 'gemeenschap' en 'het spreken van waarheid' implementeerde Call (2011:62-63) 'gastvrijheid' als een praktijk die haar klas moest maken toteen sterke gemeenschap waarin verbinding, betrokkenheid en zorg voor elkaar goed tot uiting zouden komen. Call (2011:72) begon op het materiële niveau van gastvrijheid: zij maakte maaltijden klaar voor haar leerlingen. Ze merkte dat door het praktiseren van gastvrijheid de relatie tot haar leerlingen veranderde. Die werd in emotioneel en spiritueel opzicht moeilijker, omdat het een andere oriëntatie van het hart vraagt.

Arrington (2017:27-28) wilde haar studenten trainen om zich ook buiten het klaslokaal te gedragen als Christelijke wereldburgers. Zij ontwierp daartoe het gastvrijheidsproject. Studenten moesten allereerst de Christelijke praktijk van gastvrijheid bestuderen. Maar daarna moesten ze hun eigen gastvrijheid gestalte geven door een interculturele ontmoeting te organiseren. Zij moesten iets organiseren waarin zij iemand van een andere cultuur zouden ontmoeten. Studenten gaven aan dat die activiteit vaak bestond uit het organiseren van een maaltijd. Uit de rapportages van de studenten destilleerde Arrington (2017:30) enkele algemene uitkomsten uit haar onderzoek. Gastvrijheid vraagt volgehouden aandacht. Het vraagt van beide partijen ook wederkerigheid. Gastvrijheid leidt tot transformatie van de betrokkenen en van de relaties tussen beiden.

Cooling (2015, 2016) beschrijft op zijn beurt een onderzoeksproject waarin wordt nagegaan hoe de implementatie van What If learning leraren in het basisonderwijs in staat stelt om lessen te ontwikkelen die gericht zijn op bevordering van gastvrijheid bij de leerlingen. Gastvrijheid wordt gezien als een deugd die ontwikkeld kan worden in het kader van karaktervorming. In dit project wordt het gezien als een Christelijke kerndeugd die een antwoord vormt op verscheidenheid, ook verscheidenheid in godsdienst. In de What If benadering stelt de leraar bij het overdenken van (bestaande) lessen drie vragen (Cooling 2016):

(1) How could a Christian understanding of hospitality as an appropriate response to experiencing diversity provide a different way of seeing a lesson/unit/topic? (2) How could the students engage with this new way of responding to diversity through the learning experiences teachers design? (3) How can I change my own practices to create a hospitable response to diversity? (p. 4) 
Drie stappen zijn dus te onderscheiden: '(1) Seeing anew; (2) Choosing engagement; (3) Reshaping practice'. In het project werd deze benadering toegepast in diverse vakken van het curriculum. De uitkomsten van het project waren dat leerlingen een minder negatief oordeel hadden over mensen die zij karakteriseerden als anders dan zijzelf en dat hun bereidheid om gastvrij te zijn toenam gedurende het project. Bij leraren nam het gevoel toe dat zij in staat waren om gastvrijheid als een deugd te onderwijzen en ook nam hun begrip van en bekwaamheid tot karaktervorming bij de leerlingen toe.

Uit de bovenstaande voorbeelden blijkt dat gastvrijheid een plaats heeft in onderwijs en onderwijsonderzoek. Er is reden om daar voortdurend mee bezig te zijn, want het bevorderen van gastvrijheid heeft te maken met karaktervorming van leerlingen. Het gaat daarbij om het vormen van een tweede natuur, een goede gewoonte, een habitus die zich nagenoeg als een automatisme voordoet (Wright 2010:8-9). Het vormen van zo'n tweede natuur, die door Wright 'deugd' wordt genoemd (Wright 2010:8), vraagt tijd en inspanning. Het is een uitdaging om te onderzoeken hoe in het onderwijs de deugd 'gastvrijheid' het best kan worden gevormd.

\section{Conclusies}

Zoals hierboven uiteengezet is, kan een houding van tolerantie ten opzichte van hen die van ons verschillen (bijvoorbeeld in termen van religie, cultuur of geslacht) gezien worden als een concept met beperkingen. Het ademt een sfeer van passiviteit (tolereren zonder het werkelijk accepteren van of aanpassen aan de ander en zijn verschillen), asymmetrie (mijn waarden zijn correct en ik tolereer slechts de waarden van een ander) en egocentrisme (mijn waarden, gezichtspunten en houdingen staan centraal en zijn uiteindelijk bepalend). Het begrip gastvrijheid blijkt zich inderdaad te lenen om de tekorten van het tolerantiebegrip aan te vullen. Vandaar dat wij voorstellen om de notie en de houding van (religieuze) tolerantie uit te breiden door er de notie en de houding van gastvrijheid ten opzichte van de ander (die van ons verschilt in onder andere religieus en cultureel opzicht) aan te verbinden.

Aan het begin van dit artikel werd de vraag gesteld of 'gastvrijheid' een goed Bijbels te funderen begrip is en als aanvulling kan dienen van het begrip '(religieuze) tolerantie'. De conclusie van dit artikel is dat 'gastvrijheid' inderdaad een goed Bijbels te funderen begrip is dat als een waardevolle aanvulling of uitbreiding kan dienen van (religieuze) tolerantie. Waar tolerantie veel meer een overtuiging is, kan gastvrijheid worden gezien als een samenstel van daadwerkelijke gedragingen die voor anderen waarneembaar zijn. Achter die gedragingen gaan houdingen en gezindheden schuil, waarvan tolerantie er één is. Enerzijds vereist gastvrijheid tolerantie, maar anderzijds komt tolerantie tot uiting in daden van gastvrijheid. Een keuze tussen beide begrippen is dus niet aan de orde. Beide begrippen hebben een eigen (gebruiks)waarde, ook in het onderwijs.
Daarom kan dit artikel worden gelezen als een pleidooi voor een opzettelijke conceptuele en kennistheoretische uitbreiding van (passieve) tolerantie met (actief, integrerend en inclusief) gastvrijheidsonderwijs. Het idee van gastvrijheid stelt opvoeders (leraren, ouders en andere opvoeders) beter in staat om concreet vorm te geven aan hun opdracht om op te voeden tot burgers die open staan voor anderen dan het tolerantiebegrip. Gastvrijheid betekent juist dat mensen gericht zijn op anderen, vooral op degenen die op de één of andere manier (ook religieus) anders zijn, om hen liefderijk tegemoet te treden, begrip voor hen te tonen en hun belangen op het hart te dragen, ook als dat risico's met zich mee brengt.

\section{Erkenning \\ Tegenstrijdige belangen}

De auteurs verklaren geen financiële of persoonlijke belangen te hebben die hem ongepast kunnen hebben beïnvloed bij het schrijven van dit artikel.

\section{Auteursbijdragen}

N.A.B. was responsible for the educational elements in the text. He translated the text into the Dutch language, put it in the right format and edited the final draft. A.d.M. brought in the pedagogical content. F.J.P.contributed mainly to the philosophical framework. J.L.v.d.W. wrote the sections about the Biblical underpinnings. C.C.W.W. wrote the more general sections.

\section{Literatuurverwijzingen}

Anderson, A., 2013, ' 10 of the worst terror attacks by Extreme Christians and Far-Right White men', viewed 14 January 2016, from www.alternet.org/tea-party-andright/10-worst-terror-attacks-extreme-christians-and-far-right-white-men

Anderson, D.W., 2011, 'Hospitable classrooms: Biblical hospitality and inclusive education', Journal of Education and Christian Belief 15(1), 13-27. https://doi. org/10.1177/205699711101500103

Arrington, A., 2017, 'Becoming a world Christian: Hospitality as a framework for engaging Otherness', International Journal of Christianity \& Education 21(1), 26-38. https://doi.org/10.1177/2056997116674972

Aubakirova, S.S., Ismagambetwa, Z.N., Karabayeva, Z.N., Karabayeva, A.C., Rysbekova S.S. \& Mirzbekova, A.S., 2016, 'Tolerance issue in Kazakh culture', International Journal of Environmental and Science Education 11(12), 5034-5048.

Beaman, L.G., 2011, “'It was all slightly unreal”: What's wrong with tolerance and accommodation in the adjudication of religious freedom?', Canadian Journal of Women \& the Law 38(2), 442-463. https://doi.org/10.3138/cjwl.23.2.442

Broer, N.A., De Muynck, A., Potgieter, F.J., Van der Walt, J.L. \& Wolhuter, C.C., 2016 'Het vaststellen van de mate van religieuze tolerantie bij leraren in opleiding', HTS Teologiese Studies/Theological Studies 72(3), a3158. https://doi.org/10.4102/hts. v72i3.3158

Broer, N.A., De Muynck, A., Potgieter, F.J., Wolhuter, C.C. \& Van der Walt, J.L., 2014 'Measuring religious tolerance among final year education students - The birth of a questionnaire', International Journal of Religious Freedom 7(1/2), 77-96.

Burwell, R. \& Huyser, M., 2013, 'Practicing hospitality in the classroom', Journal of Education and Christian Belief 17(1), 9-24. https://doi.org/10.1177/2056997 11301700103

Call, C., 2011, 'The rough trail to authentic pedagogy: Incorporating hospitality, fellowship, and testimony into the classroom', in D.I. Smith \& J.K.A. Smith (eds.), Teaching and Christian practices reshaping faith and learning, pp. 61-79, Wm Eerdmans, Grand Rapids, MI.

Carson, D.A., 2012, The intolerance of tolerance, Eerdmans, Grand Rapids, MI.

Cooling, T., 2015, What if learning character development project - Intervention document, The Church of England Education Office, London.

Cooling, T., 2016, What if learning character development project - Final report (initia phase), The Church of England Education Office, London.

DBE - South Africa: Department of Basic Education, 2011, Curriculum and assessment policy statement/national curriculum statement, English version, Department of Basic Education, Pretoria. 
De Rooy, P., 2014, Ons Stipje op de Waereldkaart: De politieke cultuur van Nederland in de negentiende en twintigste eeuw, Wereldbibliotheek, Amsterdam.

Derrida, J., 1999, Adieu, transl. P.A. Brault \& M. Naas, Stanford University Press, Stanford, CA.

Derrida, J., 2000, Of hospitality: Anne Dufourmantelle invites Jacques Derrida to respond, Stanford University Press, Stanford, CA.

Derrida, J., 2001, On cosmopolitanism and forgiveness, Routledge, London.

Derrida, J., 2002, 'Hospitality', in G. Anidjar (transl.), Acts of religion, pp. 356-420, Routledge, New York.

Dijkgraaf, J., 2017, De bezorgde burger; gaat Nederland naar de knoppen?, Just Publishers, Meppel.

Engeland, C., 2016, 'South Africa's murder rate climbs 4.9 percent to 51 killings every day', The Independent 03 September, viewed 14 June 2017, from http://www. independent.co.uk/news/world/africa/south-africa-murder-rate-51-killed-everyday-rise-49-per-cent-a72241

Erisen, C. \& Kenmen-Cin, C., 2017, 'Tolerance and perceived threat of Muslim immigrants in Germany and the Netherlands', European Union Politics 18(1), 73-97. https://doi.org/10.1177/1465116516675979

Francis, A., 2012, Hospitality and community after Christendom, Paternoster Authentic Publishers, Milton Keynes.

Greven, J. \& Letschert, J., 2006, Kerndoelen Primair onderwijs, Ministerie van Onderwijs, Cultuur en Wetenschap, Den Haag (Ministry of Education, Culture and Science, The Hague).

Hemmington, N. \& Gibbons, A., 2017, '“Pas d'hospitalite': Derrida and the study of hospitality in education', Hospitality and Society 7(2), 115-131. https://doi. org/10.1386/hosp.7.2.115_1

Kruger, F., 2017, 'Die ruimte van gasvryheid binne die plaaslike kerk', Die Kerkblad 119(3313), 8-9.

Naumenko, E.A. \& Naumenko, O.N., 2016, 'Pedagogical experience on formation of tolerant and multicultural consciousness', European Journal of Contemporary Education 17(3), 335-343.

Pohl, C.D., 1999, Making room - Recovering hospitality as a Christian tradition, Wm. B. Eerdmans, Grand Rapids, MI.
Potgieter, F.J., 2016, 'Teach your children well: Arguing in favour of pedagogically justifiable hospitality education', in N. Popov (ed.), Education provision to every one: Comparing perspectives from around the world. BCES Conference Books, vol. one: Comparing perspectives from around the
$14(1)$, pp. 30-36, Investpress, Sofia, Bulgaria.

Potgieter, F.J., Van der Walt, J.L. \& Wolhuter, C.C., 2014, 'Towards understanding (religious) (in)tolerance in education', HTS Teologiese Studies/Theological Studies 70(3), Art. \# 1977, 1-8. https://doi.org/10.4102/hts.v70i3.1977

Rodden, J., 2004, 'Forgiveness, education, public policy: The road not yet taken', Modern Age Fall, 333-341.

Scholtz, L., 2015, 'Volksverskuiwing: Europa is raadop', Beeld 01 September, p. 13.

United States Department of State. Bureau of Democracy, Human Rights and Labor, 2014, International Religious Freedom Report for 2014. Executive Summary, US Department of State, Washington, DC.

Van der Walt, J.L., 2014, Measuring religious tolerance in education: Towards an instrument for measuring religious tolerance among educators and their students worldwide, viewed 10 June 2015, from https://www.driestar-educatief.nl/ medialibrary/Driestar/Engelse-website/Documenten/2014-VanderWaltMeasuring-religious-tolerance-in-education.pdf

Van der Walt, J.L., 2016, "Religious tolerance and intolerance: "Engravings" on the soul', In die Skriflig 50(1), a2016. https://doi.org/10.4102/ids.v50i1.2016

Van der Walt, J.L. \& Potgieter, F.J., 2012, 'Research method in education: The frame by which the picture hangs', International Journal of Multiple Research Approaches 6(3), 220-232. https://doi.org/10.5172/mra.2012.2096

Van der Walt, J.L., Potgieter, F.J., Wolhuter, C.C., De Muynck, B. \& Broer, N.A., 2015, 'Die stand van interreligieuse toleransie by'n groep Suid-Afrikaanse onderwysstudente', KOERS - Bulletin for Christian Scholarship 80(2), Art. \#2224, 1-12.

Visser-Vogel, E., 2015, Religious identity development of orthoprax Muslim adolescents in the Netherlands, Utrecht University Repository, Utrecht.

Wright, N.T., 1996, The Lord and his prayer, SPCK, London.

Wright, N.T., 2010, Virtue reborn, SPCK, London.

Zakin, A., 2012, 'Hand to hand: Teaching tolerance and social justice one child at a time', Childhood Education 88(1), 3-13. https://doi.org/10.1080/00094056.2012. 643709 